\title{
To breastfeed or not to breastfeed? Lack of evidence on the presence of SARS-CoV-2 in breastmilk of pregnant women with COVID-19
}

\author{
Paulo Ricardo Martins-Filho ${ }^{1}$, Victor Santana Santos ${ }^{2}$ and Hudson P. Santos Jr. ${ }^{3}$
}

Suggested citation Martins-Filho PR, Santos VS and Santos Jr. HP. To breastfeed or not to breastfeed? Lack of evidence on the presence of SARSCoV-2 in breastmilk of pregnant women with COVID-19. Rev Panam Salud Publica. 2020;44:e59. https://doi.org/10.26633/ RPSP.2020.59

ABSTRACT

Keywords

\begin{abstract}
A rapid systematic review was carried out to evaluate the current evidence related to the presence of SARSCoV-2 in breast milk from pregnant women with COVID-19. Eight studies analyzing the presence of SARS-CoV-2 RNA in the breast milk of 24 pregnant women with COVID-19 during the third trimester of pregnancy were found. All patients had fever and/or symptoms of acute respiratory illness and chest computed tomography images indicative of COVID-19 pneumonia. Most pregnant women had cesarean delivery (91.7\%) and two neonates had low birthweight $(<2500 \mathrm{~g})$. Biological samples collected immediately after birth from upper respiratory tract (throat or nasopharyngeal) of neonates and placental tissues showed negative results for the presence SARS-CoV-2 by RT-PCR test. No breast milk samples were positive for SARS-CoV-2 and, to date, there is no evidence on the presence of SARS-CoV-2 in breast milk of pregnant women with COVID-19. However, data are still limited and breastfeeding of women with COVID-19 remains a controversial issue. There are no restrictions on the use of milk from a human breast milk bank.
\end{abstract} Coronavirus infection; virus diseases; pneumonia, viral; pandemics; SARS virus; breast feeding.

SARS-CoV-2 is a novel emerged positive-strand RNA virus associated with an acute respiratory distress disease known as COVID-19. Studies have suggested that transmission of SARS-CoV-2 is primarily from person to person through respiratory droplets $(1,2)$. In addition, there is emergent evidence that the virus could be detected in biological fluids including bronchoalveolar lavage fluid specimens (3), blood $(3,4)$ and saliva (5), but substantial knowledge gaps remain regarding the presence of SARS-CoV-2 in the breast milk. Recently, a report in Science discussed the wrenching choices of pregnant women with COVID-19 after childbirth including whether or not they should breastfeed their children (6).

\section{METHODS}

We performed a rapid systematic review to evaluate the current evidence related to the presence of SARS-CoV-2 in breast milk from pregnant women with COVID-19. The study was conducted in accordance with the Preferred Reporting Items for Systematic reviews and Meta-Analyses (PRISMA) guidelines (7), but given emergency-need for this review, PROSPERO registration was not sought. Using terms related to coronavirus, we searched in PubMed, Web of Science, Scopus, China National Knowledge Infrastructure database, and grey literature (Google Scholar and preprint repositories) to identify studies reporting results of RT-PCR tests on breast milk in pregnant women with

\footnotetext{
Federal University of Sergipe, São Cristóvão, Brazil $₫$ Paulo Ricardo Martins-Filho, saqmartins@hotmail.com

2 Universidade Federal de Alagoas, Arapiraca, Brazil
} 3 University of North Carolina at Chapel Hill, Chapel Hill, United States of
America. 


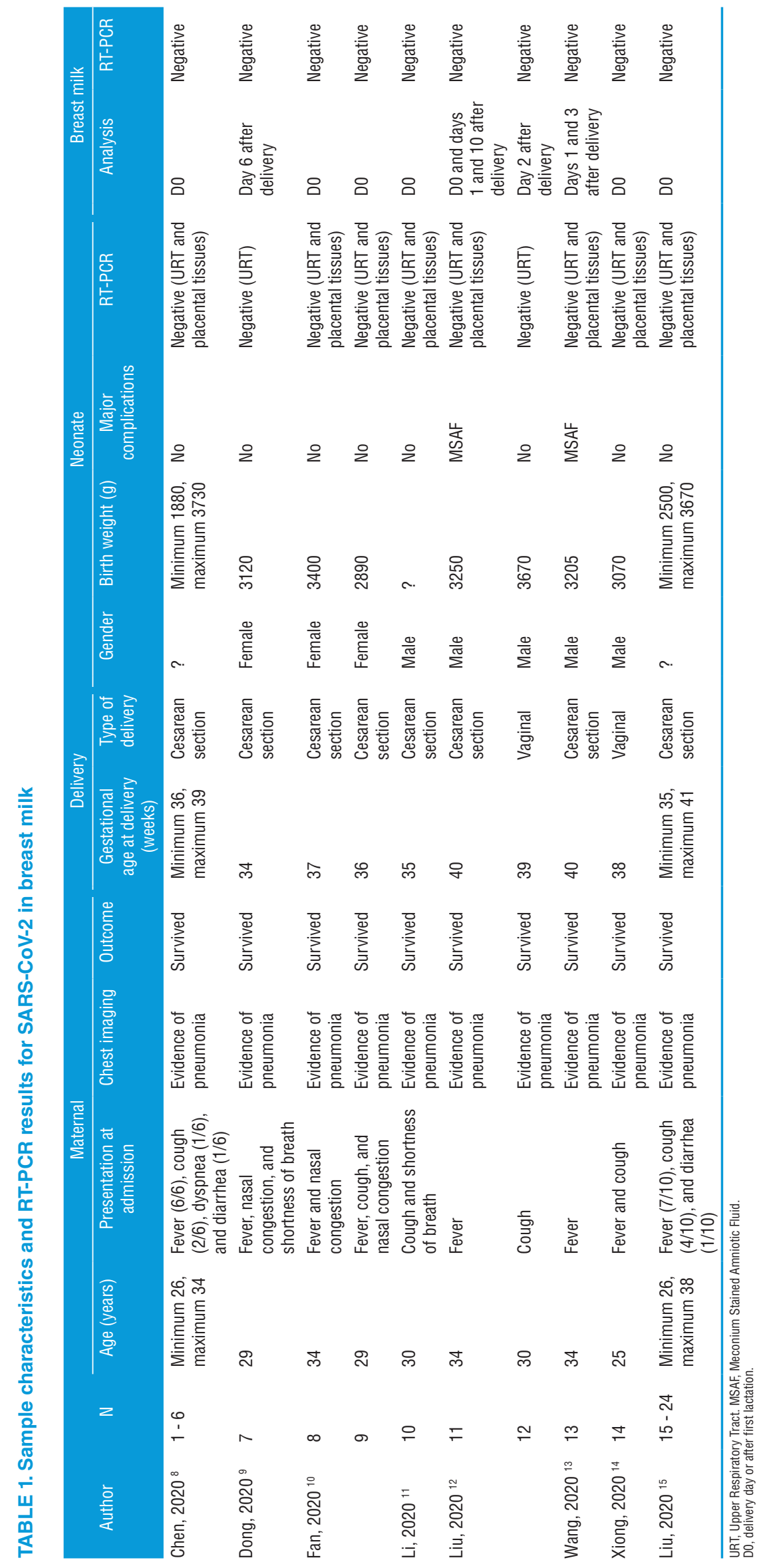


laboratory-confirmed SARS-CoV-2 infection. Searches were performed up to March 30, 2020 and updated on April 21, 2020.

\section{RESULTS AND DISCUSSION}

We found eight studies (8-15) analyzing the presence of SARS-CoV-2 RNA in the breast milk of 24 pregnant women with COVID-19 during the third trimester of pregnancy (Table 1). All patients had fever and/or symptoms of acute respiratory illness and chest computed tomography (CT) images indicative of COVID-19 pneumonia. Most pregnant women had cesarean delivery $(91.7 \%)$ and two neonates had low birthweight $(<2,500$ g). Biological samples collected immediately after birth from upper respiratory tract (throat or nasopharyngeal) of neonates and placental tissues showed negative results for the presence SARS-CoV-2 by RT-PCR test. In addition, no breast milk samples were positive for SARS-CoV-2. In three studies $(10,12,13)$ there was a clear recommendation for mother's to not breastfeed their children despite the lack of evidence on the potential viral transmission via breast milk.

As the coronavirus pandemic takes hold, pregnant women infected with SARS-CoV-2 experience fear and uncertainties regarding the care of their child. Making decisions without a robust evidence base may influence mother-child interactions and lead to poor outcomes. Furthermore, there is a lack of consensus among health agencies regarding breastfeeding for women with COVID-19. In February 2020, the National Health Commission of China recommended that neonates of pregnant women with suspected or confirmed COVID-19 should be isolated in a designated unit for at least 14 days and should not be breastfeed due to the high risk of infection (16). Although this expert working group has suggested breastfeeding only in cases of negative tests for SARS-CoV-2, this warning may contribute to reducing breastfeeding by women with no exposure to the virus which may lead to infant poor health outcomes. On the other hand, interim guidance provided by the Centers for Disease Control and Prevention (CDC) (17) and the World Health Organization (WHO) (18) advises that breastfeeding should be determined by the mother in coordination with her family and healthcare providers, and all possible prevention measures to avoid spreading the virus to the infant must be taken including wearing a mask and washing hands and breasts with soap and water before breastfeeding. If the woman opts to express breast milk, all recommendations for cleaning the breast pumps and utensils after each use must be rigorously followed. Consideration should be given to the possibility of someone healthy providing breast milk to the infant using a cup or spoon. This person must receive training from a qualified professional before starting procedures. If there is no production of breast milk by the mother, a human milk bank should be contacted. There are no restrictions on the use of milk from a human breast milk bank $(19,20)$. The possibility of drug excretion into breast milk with potential adverse effects in breastfeed neonates should also be analyzed (21). To date, there is no evidence on the presence of SARS-CoV-2 in breast milk of pregnant women with COVID-19. Data provided on current literature are still limited and breastfeeding of women with COVID-19 remains a controversial issue. Further studies with large samples are needed to confirm these results particularly given the importance of breastfeeding in preventing other childhood illnesses.

\section{Conflict of interest. None declared.}

Author contributions. All authors conceived the original idea and contributed to the analysis and interpretation of the results. All authors reviewed and approved the final version.

Disclaimer. Authors hold sole responsibility for the views expressed in the manuscript, which may not necessarily reflect the opinion or policy of the RPSP/PAJPH or the Pan American Health Organization (PAHO).

\section{REFERENCES}

1. Chan JF-W, Yuan S, Kok K-H, To KK-W, Chu H, Yang J, et al. A familial cluster of pneumonia associated with the 2019 novel coronavirus indicating person-to-person transmission: a study of a family cluster. Lancet. 2020 Feb;395(10223):514-23.

2. Ghinai I, McPherson TD, Hunter JC, Kirking HL, Christiansen D, Joshi K, et al. First known person-to-person transmission of severe acute respiratory syndrome coronavirus 2 (SARS-CoV-2) in the USA. Lancet [Internet]. 2020 Mar 13; Available from: http://www. ncbi.nlm.nih.gov/pubmed/32178768

3. Wang W, Xu Y, Gao R, Lu R, Han K, Wu G, et al. Detection of SARSCoV-2 in Different Types of Clinical Specimens. JAMA [Internet]. 2020 Mar 11; Available from: https://jamanetwork.com/journals/ jama/fullarticle/2762997

4. Young BE, Ong SWX, Kalimuddin S, Low JG, Tan SY, Loh J, et al. Epidemiologic Features and Clinical Course of Patients Infected With SARS-CoV-2 in Singapore. JAMA [Internet]. 2020 Mar 3; Available from: http:/ / www.ncbi.nlm.nih.gov/pubmed/32125362

5. To KK-W, Tsang OT-Y, Chik-Yan Yip C, Chan K-H, Wu T-C, Chan JMC, et al. Consistent detection of 2019 novel coronavirus in saliva. Clin Infect Dis [Internet]. 2020 Feb 12; Available from: http:/ / www. ncbi.nlm.nih.gov/pubmed/32047895

6. Vogel G. New coronavirus leaves pregnant women with wrenching choices-but little data to guide them. Science (80- ) [Internet].
2020 Mar 27; Available from: https://www.sciencemag.org/ news/2020/03/new-coronavirus-leaves-pregnant-women-wrench ing-choices-little-data-guide-them

7. Moher D, Liberati A, Tetzlaff J, Altman DG. Preferred reporting items for systematic reviews and meta-analyses: the PRISMA statement. Int J Surg [Internet]. 2010 Jan [cited 2014 Jul 10];8(5):336-41. Available from: http://www.ncbi.nlm.nih.gov/pubmed/20171303

8. Chen H, Guo J, Wang C, Luo F, Yu X, Zhang W, et al. Clinical characteristics and intrauterine vertical transmission potential of COVID-19 infection in nine pregnant women: a retrospective review of medical records. Lancet. 2020;395(10226):809-15.

9. Dong L, Tian J, He S, Zhu C, Wang J, Liu C, et al. Possible Vertical Transmission of SARS-CoV-2 From an Infected Mother to Her Newborn. JAMA [Internet]. 2020 Mar 26;53(9):1689-99. Available from: https://jamanetwork.com/journals/jama/fullarticle/2763853

10. Fan C, Lei D, Fang C, Li C, Wang M, Liu Y, et al. Perinatal Transmission of COVID-19 Associated SARS-CoV-2: Should We Worry? Clin Infect Dis [Internet]. 2020 Mar 17; Available from: https:/ / academic. oup.com/cid/advance-article/doi/10.1093/cid/ciaa226/5809260

11. Li Y, Zhao R, Zheng S, Chen X, Wang J, Sheng X, et al. Lack of Vertical Transmission of Severe Acute Respiratory Syndrome Coronavirus 2, China. Emerg Infect Dis [Internet]. 2020 Jun 17;26(6). Available from: http://www.ncbi.nlm.nih.gov/pubmed/32134381 
12. Liu W, Wang Q, Zhang Q, Chen L, Chen J, Zhang B, et al. Coronavirus disease 2019 (COVID-19) during pregnancy: a case series. Preprints. 2020;(February):1-28.

13. Wang S, Guo L, Chen L, Liu W, Cao Y, Zhang J, et al. A case report of neonatal COVID-19 infection in China. Clin Infect Dis [Internet]. 2020 Mar 12; Available from: http://www.ncbi.nlm.nih.gov/ pubmed/32161941

14. Xiong X, Wei H, Zhang Z, Chang J, Ma X, Gao X, et al. Vaginal Delivery Report of a Healthy Neonate Born to a Convalescent Mother with COVID-19. J Med Virol [Internet]. 2020 Apr 10; Available from: http:/ / www.ncbi.nlm.nih.gov/pubmed/32275072

15. Liu W, Wang J, Li W, Zhou Z, Liu S, Rong Z. Clinical characteristics of 19 neonates born to mothers with COVID-19. Front Med [Internet]. 2020 Apr 13; Available from: http://link.springer. com/10.1007/s11684-020-0772-y

16. Wang L, Shi Y, Xiao T, Fu J, Feng X, Mu D, et al. Chinese expert consensus on the perinatal and neonatal management for the prevention and control of the 2019 novel coronavirus infection (First edition). Ann Transl Med [Internet]. 2020 Feb;8(3):47. Available from: http://www.ncbi.nlm.nih.gov/pubmed/32154287

17. Centers for Disease Control and Prevention. Centers for Disease Control and Prevention. Pregnancy \& Breastfeeding [Internet]. 2020 [cited 2020 Mar 18]. Available from: https://www.cdc. gov/coronavirus/2019-ncov/prepare/pregnancy-breastfeeding
.html?CDC_AA_refVal=https\%3A\%2F\%2Fwww.cdc.gov\%2F coronavirus $\% 2 \mathrm{~F} 2019-$ ncov $\% 2$ Fspecific-groups $\% 2$ Fpregnancy-faq. html\#anchor_1584169714

18. World Health Organization. Home care for patients with COVID19 presenting with mild symptoms and management of their contacts. Interim guidance [Internet]. 2020 [cited 2020 Mar 17]. p. 1-4. Available from: https://www.who.int/publications-detail/ home-care-for-patients-with-suspected-novel-coronavirus-(ncov)infection-presenting-with-mild-symptoms-and-management-ofcontacts

19. Center for Disease Control and Prevention (CDC). Interim Considerations for Infection Prevention and Control of Coronavirus Disease 2019 (COVID-19) in Inpatient Obstetric Healthcare Settings [Internet]. Available from: https:/ / www.cdc.gov/coronavirus/2019-ncov/hcp/inpatient-obstetric-healthcare-guidance.html

20. Royal College of Obstetricians and Gynaecologists. Coronavirus (COVID-19) Infection in Pregnancy. Information for healthcare professionals. Version 1: Published Monday 9 March, 2020 [Internet]. Available from: https://www.rcog.org.uk/globalassets/ documents/guidelines/coronavirus-co

21. Anderson PO. Breastfeeding and Respiratory Antivirals: Coronavirus and Influenza. Breastfeed Med [Internet]. 2020 Mar 1;15(3):128-128. Available from: https://www.liebertpub.com/ doi/10.1089/bfm.2020.29149.poa

\section{Lactancia materna en mujeres con COVID-19: falta de evidencia sobre la presencia de SARS-CoV-2 en la leche materna}

RESUMEN Se llevó a cabo una revisión sistemática rápida para evaluar la evidencia disponible sobre la presencia de SARS-CoV-2 en la leche materna de mujeres embarazadas afectadas con COVID-19. Se encontraron ocho estudios que analizaron la presencia de ARN de SARS-CoV-2 en la leche materna de 24 mujeres embarazadas con COVID-19 durante el tercer trimestre del embarazo. Todas las pacientes tenían fiebre o síntomas de enfermedad respiratoria aguda e imágenes de tomografía computarizada de tórax indicativas de neumonía por COVID-19. La mayoría de las mujeres embarazadas $(91,7 \%)$ tuvieron un parto por cesárea y dos neonatos presentaron bajo peso al nacer $(<2500 \mathrm{~g})$. Las muestras biológicas recogidas inmediatamente después del parto de las vías respiratorias superiores (faringe o nasofaringe) de los neonatos y los tejidos placentarios mostraron resultados negativos para SARS-CoV-2 mediante RT-PCR. Ninguna muestra de leche materna fue positiva para SARS-CoV-2 y, hasta la fecha, no hay evidencia de la presencia de SARS-CoV-2 en la leche materna de las mujeres embarazadas con COVID-19. Sin embargo, los datos disponibles todavía son limitados y la lactancia materna en las mujeres con COVID-19 sigue siendo un tema controvertido. No hay restricciones para el uso de leche materna de banco.

Palabras clave Infecciones por coronavirus; virosis; pandemias; virus del SRAS; lactancia materna. 


\section{Aleitamento materno em mulheres com COVID-19: falta de evidência da presença da SARS-CoV-2 no leite materno}

RESUMO Foi realizada uma revisão sistemática rápida para avaliar as evidências atuais relacionadas à presença da SARS-CoV-2 no leite materno de mulheres grávidas com COVID-19. Foram encontrados oito estudos analisando a presença de RNA do SARS-CoV-2 no leite materno de 24 gestantes com COVID-19 durante o terceiro trimestre de gravidez. Todas as pacientes apresentavam febre ou sintomas de doença respiratória aguda e imagens de tomografia computadorizada do tórax indicativas de pneumonia pela COVID-19. A maioria das gestantes teve parto cesáreo $(91,7 \%)$ e dois recém-nascidos tiveram baixo peso ao nascer $(<2500 \mathrm{~g})$. As amostras biológicas coletadas imediatamente após o nascimento do trato respiratório superior (faringe ou nasofaringe) de neonatos e tecidos placentários apresentaram resultados negativos para a presença do SARS-CoV-2 pelo teste RT-PCR. Nenhuma amostra de leite materno foi positiva para o SARS-CoV-2 e, até à data, não há evidências da presença do SARS-CoV-2 no leite materno de mulheres grávidas com COVID-19. No entanto, os dados ainda são limitados e a amamentação de mulheres com COVID-19 continua a ser uma questão controversa. Não há restrições ao uso de leite de um banco de leite materno humano.

Palavras-chave Infecções por coronavirus; viroses; pandemias; vírus da SARS; aleitamento materno. 